\title{
PROFECIA E SANTIDADE: experiência religiosa de João Maria
}

\author{
Prophecy and holiness: \\ religious experience of João Maria
}

\begin{abstract}
Gilberto Tomazi
Mestrado e doutorando em Ciências da Religião pela PUC-SP, Docente do Instituto Teológico de Santa Catarina - ITESC (Professor de Ciências da Religião), Coordenador Diocesano de Pastoral - Caçador, Santa Catarina, SC - Brasil, e-mail: giltom3@gmail.com
\end{abstract}

\section{Resumo}

Este artigo visa recuperar alguns aspectos da mensagem, da mística e da missão de João Maria d'Agostini, considerado profeta e santo na região onde, entre os anos de 1912 a 1916, aconteceu a guerra do Contestado. Destacaremos as principais idéias que o moveram e que estiveram na base de suas pregações e diálogos. Este artigo procura considerar a sua mensagem mais original, aquela que se encontra nas mais diferentes obras existentes que tratam do assunto. Queremos, com isso, abrir um caminho de compreensão da mensagem de João Maria e de como ela foi sendo ressignificada junto aos descendentes do Contestado. Este artigo apresenta aspectos relacionados à vida, aos costumes, à religiosidade, à moral, à cosmo visão e demais dimensões da vida humana e da biodiversidade, contidas no discurso de João Maria e na memória popular do Contestado a seu respeito.

Palavras-chave: Cultura popular; Experiência religiosa; Contestado; João Maria d'Agostini. 


\begin{abstract}
This article seeks to recover some aspects of the message, the mystical and mission of João Maria d'Agostini, considered prophet and saint in the area where, from the year 1912 to 1916, the Constestado war took place. We will highlight the main ideas that moved him and were the basis of his preaching and dialogues. This article seeks to consider his more original message, which is in the most different existent works that deal with the topic. We want, herewith, to open a path of understanding of João Maria's message and how it has reached a new signification close to the descendants of the Contestado. This article presents aspects related to the life, to the habits, to the religiosity, to the morals, to the Cosmo vision and other dimensions of the human life and of the bio-diversity, contained in João Maria's speech and in the popular memory of the Contestado about it.
\end{abstract}

Keywords: Popular culture; Religious experience; Contestado; João Maria d'Agostini.

\title{
Introdução
}

A guerra do Contestado aconteceu durante os anos de 1912 a 1916 e abrangeu uma região que equivale hoje a, aproximadamente, $1 / 3$ do território catarinense, abrangendo o meio oeste, o planalto norte e a região serrana, e, mais parte do sul e sudoeste do Paraná. O termo "Contestado" remonta a meados do século XIX quando teve início a disputa dos limites territoriais entre os Estados de Santa Catarina e Paraná. Tal disputa só foi concluída em 1916, ano em que foi assinado o acordo definitivo sobre os limites entre os dois Estados. Foram 48 mil quilômetros quadrados de terras disputados, que compunham o "chão Contestado". O Contestado continua, hoje, muito presente na vida de sofrimento e na memória dos descendentes que viveram a sua luta. Cerca de 2/ 3 de toda a força militar existente no Brasil, na época, foi utilizada contra o movimento do Contestado. Foram colocados nas mãos dos militares e vaqueanos, canhões, metralhadoras e até mesmo aviões, com a finalidade de 
"limpar a área" que deveria ser colonizada e modernizada. Ao que tudo indica, a elite do país queria acabar com o atraso do sertão e com as superstições e misticismos que dominavam mentes e corações de grande parte de sua população. Acreditavam que só assim este país poderia avançar, evoluir, progredir, desenvolver-se e industrializar-se. Na região do Contestado, para acabar com mitos, fantasias, ignorância e fanatismo, dos quais as culturas religiosa e popular encontravam-se recheadas, foi necessário fomentar uma guerra e acabar com grande parte da população que habitava a região.

Mas quem era essa população que se reunia em redutos, no Contestado, para resistir contra as armas da violência e da morte? E onde eles encontraram motivações, autoestima e coragem para lutar por um mundo que fizesse sentido, um mundo de inclusão, justiça e solidariedade? Em grande parte, foi em João Maria que milhares de pessoas, no passado ou no presente, encontram essa referência de resistência, esperança e sentido para a vida e a história.

João Maria, reconhecido como profeta e santo junto à cultura popular do Contestado, talvez não seja um único personagem histórico, mas dois ou mais. De qualquer forma, é apenas um personagem com este nome que, aos poucos, passou a ser uma figura lendária, um mito, uma "síntese". É como um ícone ou um mosaico construído por muitas mãos, sonhos e a partir de diferentes materiais. Quanto ao período da presença histórica de João Maria na região do Contestado, não há consenso; a data varia desde meados do século XIX até o final da primeira década do século XX. Sua presença, porém, vai além dos registros históricos. Segundo a crença popular ele continua encantado; ele vive!

O Contestado é considerado um dos maiores movimentos populares da história do Brasil e, até o momento, poucos espaços foram abertos para uma leitura mais aprofundada e coerente dos seus aspectos culturais e religiosos. Neste artigo, não faremos uma abordagem sócio-histórica da região e nem do Contestado. Para isso, diversos estudos já foram realizados e estão citados nas referências bibliográficas. O que queremos apresentar aqui é parte da mensagem, da mística e da vida de João Maria, considerado profeta e santo por um grande número de pessoas que vivem no sul do Brasil e, especialmente, pelos descendentes do Contestado, na sua maioria, caboclos.

Neste artigo apresentaremos fundamentalmente os aspectos mais originais da vida e mensagem de João Maria. Existem muitos mitos, ritos, símbolos, sacrifícios e rezas que fazem referência a João Maria e que foram preservados ou reinterpretados e re-elaborados pela cultura ou pela religiosidade 
do Contestado, a tal ponto que os descendentes do Contestado procuram manter viva a memória de João Maria como uma referência fundamental ou como um modelo de vida e, desta forma, assumem uma postura ou uma atitude mística, não de derrota nem de vingança diante da estrutura social violenta que herdaram do passado e que ainda encontram na atualidade, mas de resistência, esperança e luta por dias melhores.

Destacaremos as principais idéias que moveram João Maria e que estiveram na base de suas pregações e de sua vida. E, assim, abriremos um caminho de compreensão da mensagem original de João Maria e de como ela foi sendo ressignificada ou reinterpretada junto aos descendentes do Contestado. A grande maioria destes descendentes vive numa situação de miséria, violência, desemprego e analfabetismo. Porém, mesmo vivendo nesta situação e sendo herdeiros de uma luta inglória, há algo que os move, que faz com que continuem confiando na vida, que oferece um sentido à sua história e não os deixa desesperar. É a mística. E esta tem como referência o "São" João Maria. É agarrados nessa mística que os descendentes do Contestado, os "incultos", os "sem poder", os "sem-terra" e os "sem-direitos", procuram sobreviver neste mundo complexo e excludente. Ela é uma forma encontrada para controlar a realidade social violenta, que parece perigosa demais para ser enfrentada por outros meios, além do simbólico. João Maria abriu "as picadas", dentro da densa mata, repleta de araucárias, imbuias, erva-mate, não da busca de adaptação e submissão ao processo de modernização que vinha sendo implantado no Brasil, mas sim de um novo modo de vida, de organização social e comunitária.

Falar sobre mística, profecia e santidade em um mundo racionalista, pragmático e que prega o "fim da história", pode parecer uma volta aos tempos prémodernos ou do romantismo, mas é bom lembrar que o próprio Antônio Gramsci abriu uma janela importante da ciência política marxista quando considerou a riqueza das manifestações da cultura popular. Depois dele, tantos outros sociólogos e antropólogos como Ernest Bloch, Michael Löwy, Clifford Geertz, Renato Ortiz, Alba Zaluar compreenderam que, para além da fragmentariedade e da ambiguidade, existe uma sabedoria e um dinamismo na cultura, na religião e na organização popular que tende para a mudança, que faz com que o povo cresça em termos de consciência de classe e aprenda a filtrar as informações ou as ideologias que lhe são impostas, tornando-se capaz de enfrentar as crises, os conflitos e as tensões do seu cotidiano, resistir contra a opressão, construir alternativas de vida e nunca deixar de sonhar com um outro mundo possível. 


\section{Identidade de João Maria}

João Maria se tornou um mito na região sul do Brasil. Mais de quatro gerações já se passaram e João Maria continua vivo na memória e na vida de muitos descendentes do Contestado. Algumas pesquisas recentes feitas sobre João Maria apontam pelo menos para a existência de dois homens chamados João Maria: um seria João Maria d'Agostini e outro João Maria de Jesus, cujo nome original seria Atanás (ou Anastás) Marcaf. Há, ainda, quem sugira a existência de mais de dois monges com esse nome e com, praticamente, a mesma identidade presentes no folclore do Contestado (FELIPPE, 1995, p. 27-30). Porém, na grande maioria das pesquisas realizadas sobre João Maria, e, sobretudo naquelas realizadas mais próximas da guerra do Contestado, discorre-se sobre apenas um homem com este nome. Após fazer uma apurada revisão bibliográfica, constata-se que não há dados suficientes para provar historicamente a existência de dois João Maria. Entretanto, para defender a hipótese que houve somente um João Maria, será necessário partir do princípio que este homem teve uma vida centenária. Os descendentes do Contestado também apontam para apenas um homem com esse nome. Este homem é denominado de João Maria d'Agostini, João Maria de Jesus ou simplesmente João Maria. Na memória popular dos descendentes do Contestado houve apenas um profeta e santo com o nome João Maria, que passou pela região diversas vezes e habitou em diversas grutas e em outros locais que jamais foram esquecidos e, inclusive, muitos deles se tornaram locais de peregrinação.

Vinhas de Queiroz (1977, p. 51) oferece uma síntese sobre a vida de um João Maria, que ele sugere ter sido o primeiro monge com este nome:

O primeiro monge, de origem italiana, natural do Piemonte, onde nascera em 1801, apareceu em Sorocaba em fins de 1844. Uns três anos depois, andou pelo Rio Grande do Sul: levantou capela nos arredores de Santa Maria, ao lado de um rochedo e perto de uma nascente. Tamanha a multidão que naquele tempo se reuniu no lugar, que o presidente da província, temendo pela segurança pública, expulsou, em 1848, este João Maria para o Rio de Janeiro. Sabemos que voltou a Sorocaba. Depois, esteve na cidade da Lapa, onde ainda hoje milhares de crentes, todos os anos, acendem velas e cumprem as promessas junto à pedra onde ele dormia e a água que ali nasce ainda é tida por milagrosa. Andou em Rio Negro e em Lages, mas voltou ainda uma vez à Sorocaba, onde morreu 
em 1870, se é que não se mudou para Araraquara, onde temos notícia da existência de um João Maria, em 1906. Para que fosse o mesmo homem teria que ser mais que centenário.

Segundo Ávila da Luz (1999, p. 136) “em 1893, durante a Revolução, João Maria d'Agostini, do qual era simpatizante, andava pelo Rio Grande do Sul." Ele aponta para a existência de apenas um João Maria que se chamaria João Maria d'Agostini e que teria estado na região do Contestado em $1895 .{ }^{1}$ Ele afirma que:

Para ÁVILA DA LUZ, Ajor. Os fanáticos: crimes e aberrações da religiosidade dos nossos caboclos. 2. ed. Florianópolis: Ed. da UFSC, 1996, a existência de João Maria d'Agostini "é assinalada no Paraná, durante a Campanha de Canudos. Então seu prestígio entre os sertanejos já era enorme." Nessa época ele "enveredou novamente para o sul. Então aparece, no estado de Santa Catarina, em Canoinhas, Curitibanos, Lages e Campos Novos.” Ele diz ainda que "quando surgiu em Santa Catarina, já velho e bem identificado com seu misticismo, já era monge feito [...] falava o português corretamente, mas tinha um ligeiro sotaque castelhano, que fazia supô-lo nascido fora do Brasil. "Em FACHEL, José F. Monge João Maria: recusa dos excluídos. Porto Alegre: UFRGS; Florianópolis: Ed. da UFSC, 1995. Aparece antes do nome, Giovani Maria d'Agostini um Fr. que nos permite supor que este monge pudesse ser um Frade Agostiniano ou um membro da ordem dos eremitas de Santo Agostinho. VINHAS DE QUEIROZ, Maurício. Messianismo e conflito social: a guerra sertaneja do Contestado. 2. ed. São Paulo: Ática, 1977. Entende que houve um segundo João Maria, cujas características são praticamente as mesmas definidas por Ávila da Luz como sendo do primeiro monge. Este, porém, tem nome de João Maria de Jesus, e é "velho octogenário, monge e profeta". THOMÉ, Nilson. Sangue suor e lágrimas no chão do Contestado. Caçador, SC: UnC, 1992. Assim descreve este segundo João Maria: "Anastás Marcaf, ex-marinheiro cujo navio naufragou em frente a Buenos Aires e que, para pagar promessa, dedicou-se à peregrinação. Vindo da Argentina, entrou no Brasil pela região missioneira gaúcha, já com mais de 50 anos, ficando conhecido como monge João Maria de Jesus. Monarquista, em 1983 declarava seu apoio à Revolução Federalista, rogando pragas aos republicanos. Teve contato com o Frei Rogério, na região de Lages, em 1897, deixou marcas no Morro do Taió e no Morro das Cruzes, em Porto União. Mesmo político numa época turbulenta, não era violento, mas sim pacificador. Ficou famoso por suas profecias calamitosas e apocalípticas. Desapareceu entre 1908 e 1910, também misteriosamente. CABRAL, Oswaldo. R. A campanha do Contestado. 2. ed. Florianópolis: Lunardelli, 1979. Afirma que este (segundo) João Maria "nenhuma informação identificadora deixou de si. Apenas o Cel. J. O. Pinto Soares, em sua obra 'Guerra em Sertões Brasileiros', nos traz um subsídio, 'segundo pesquisas feitas', não indicando, infelizmente, as fontes em que o obteve." Em que está escrito que "seu nome verdadeiro era Anastás Marcaf, de origem Francesa”. 
Era um monge de estatura meã, entroncado; os cabelos crescidos e encanecidos e a barba cerrada e branca, trazia-as em desalinho; na face enegrecida e tostada pelo sol, os olhos azuis tristes e fundos tinham fulguração estranha de místico: um gorro felpudo na cabeça, umas calças curtas que deixavam à mostra os cordões da ceroula e um paletó curto e riscado, de algodão, constituíam sua modesta, mas limpa, indumentária. Completando-a, umas alpercatas e um cinto de couro cru, fabricados por ele mesmo. Ao pescoço trazia um colar de "lágrimas de Nossa Senhora", a tiracolo uma guampa com água, às costas um saco com alguma roupa, uma caneca, a cuia e bomba do chimarrão e uma lata que servia à guisa de marmita. Carregava também uma caixinha, que à maneira de pequeno oratório, encerrava uma imagem de Nossa Senhora da Abadia. [...] aparentava, na época, ter uns 50 ou 60 anos de idade.

Osvaldo R. Cabral (1979, p. 108) foi um dos primeiros pesquisadores a defender a existência, não de apenas um, mas de dois homens com o nome de João Maria. Para ele, este, supracitado, seria um segundo monge, pois o primeiro, ao final do século, deveria estar com quase 100 anos de vida e não com 50 ou 60 anos, como afirmara Ávila da Luz. De qualquer forma, Cabral também colocou dúvidas e questões quanto à existência histórica de um segundo João Maria, mas acabou por defendê-la, assegurando, mesmo sem poder documentar, que o nome que ele próprio atribuiu a si mesmo seria João Maria de Jesus.

Porém, sendo que não há qualquer registro deste personagem, podemos concluir que a questão pode ser erro de percepção e que a expressão "de Jesus", ao nome João Maria, pode ser um apelido, uma substituição ou uma qualificação posterior do próprio nome, muito comum na cultura popular que carrega consigo uma sabedoria e um imaginário capaz de renomear e reinterpretar aspectos, processos ou acontecimentos do seu cotidiano.

Desta forma, o João Maria d'Agostini, que também poderia ter sido denominado de João Maria de Jesus, é de indiscutível valor histórico. Ele foi um "homem religioso", um anacoreta que desejava a solidão e o isolamento, a vida contemplativa, as longas orações. Registrou-se em 24 de dezembro de 1844, na Câmara Municipal de Sorocaba, Província de São Paulo, onde se dizia solteiro e de profissão "solitário eremita", tendo viajado para exercer seu ministério. Achava-se residindo nas matas do Termo da Cidade, principalmente no morro da Fábrica do Ipanema (CABRAL, 1979, p. 107; FACHEL, 1995, p. 15). 
De qualquer forma, mesmo que houvesse um segundo personagem, de nome João Maria de Jesus, como alguns suspeitam, praticamente só mudaria na sua identidade uns dedos a mais ou a menos numa das mãos, a sua origem, que seria francesa (mas que tinha um sotaque espanhol e que teria nascido no mar) e não italiana, a sua possível idade, a época em que passou pela região e também a cosmo visão que parece diferenciada entre os monges, sendo o primeiro considerado mais "religioso" e o segundo mais "político". Porém, como diz o ditado popular "quem conta um conto aumenta um ponto". Variam os "olhares" do pesquisador e do pesquisado. Duas pessoas ao olharem para um fato darão duas interpretações do mesmo. Some-se a isso a ideologia e a metodologia dos pesquisadores, que também variam com o passar dos tempos, tal como a cultura popular, que também vai ressignificando os acontecimentos e adaptando-os, a seu modo e conforme seus interesses e desejos, ao seu cotidiano (SAHLINS, 1990, p. 10).

Fato é que, aos poucos, se realmente as diferenças existiam, ou seja, se verdadeiramente houve mais de uma pessoa reconhecida como o profeta João Maria, elas foram desaparecendo na tradição oral e aumentando nos escritos. Acontece aqui uma separação entre ambas, sendo necessário, portanto, assumirmos uma opção. E a opção deste artigo é pela cultura popular que trás consigo uma sabedoria que só pode ser devidamente expressa pela tradição oral.

Cabral (1979, p. 164) abriu as portas para a possibilidade da existência histórica de dois monges de nome João Maria. Ele afirma que "no sertão, no planalto, nos vales, nas coxilhas, todavia, São João Maria é um só. Não houve dois." Em um dos retratos do "santo", presente em grande parte das casas dos descendentes do Contestado, estampa-se a legenda: "João Maria de Jesus (em alguns casos, ou, João Maria d'Agostini em outros), profeta com 188 anos", como querendo afirmar que se houve dois agora já são apenas um, ou que "João Maria ainda está vivo, mesmo com toda essa idade".

João Maria d'Agostini, ou simplesmente João Maria, passou a ser o mais afamado personagem mítico do Contestado. Este personagem marcou profundamente a vida dos habitantes desta região e, também, do sul do país. João Maria foi reverenciado por muitos, mas também criticado por alguns coronéis, governantes, militares, vaqueanos e sacerdotes católicos que a ele atribuíram o título de feiticeiro, charlatão, herético, bruxo, falso profeta, perigoso, fomentador de violências e desordens, homem de má aparência e reputação, suspeito, duvidoso, lunático, "lobo vestido de ovelha" (MACHADO, 2004, 
p. 173), entre outros. Com isso ele fora vigiado, expulso, maltratado, injuriado, preso e suspeita-se, também, apedrejado e morto, enterrado como desconhecido, andarilho, alguém sem nome e sem ninguém.

Realmente, ele preferia andar sempre a sós, indefeso e desarmado. O mistério o envolvia e o atraía. Numa primeira fase de sua vida parece ter aceitado que grande número de pessoas se aglomerasse em torno de si para ouvi-lo, depois passou a preferir conversar com pequenos grupos e especialmente com cada pessoa em particular. Ele tinha senso crítico diante da realidade por isso suas palavras eram proféticas. Ele não desprezava ou desrespeitava ninguém, mas manifestava um carinho especial pelos mais pobres e sofredores.

Ele se identificou com as pessoas mais simples, místicas, dos "sertões", afastadas dos grandes centros, e, ensinou sobre ecologia, plantações, remédios, rezas, maneiras de ser e de agir, o que, como e quando se devia ou não falar, adorar, esperar, batizar, quais e quando os santos deviam ser invocados e reverenciados, como se relacionar com pessoas de outro sexo, idade e etnia e do que as pessoas deveriam se afastar e libertar. Enfim, foi sentido e recebido como um modelo de vida, experimentado como quem devia ser seguido e respeitado. Segundo Monteiro (1974, p. 84):

João Maria distribuía orações aos devotos; receitava chás de miraculosa ervinha [...]. Benzia roças para evitar a praga de gafanhotos; santificava as fontes ao lado das quais plantava uma cruz de cedro; também orientava sobre plantações e sobre lugares donde se poderia viver. A Vila do Timbó, por exemplo, foi constituída sob a orientação do monge.

\section{Idas, vindas e espaços sagrados}

Rapidamente o monge se tornou conhecido em uma grande região do país, especialmente no centro oeste e sul. Após habitar por algum tempo em Sorocaba, o eremita João Maria, que se tornou conhecido como o Monge de Ipanema, em meados do século XIX, se dirigiu ao sul do país seguindo o caminho dos tropeiros. Sorocaba era o destino de muitos comerciantes que compravam, vendiam, trocavam diversas mercadorias, especialmente muares em grande quantidade, que eram levados do Rio Grande do Sul, dos campos de Vacaria, passando pelos campos de Lages, Campos Gerais e Itararé abrindo, com isso, um dos primeiros caminhos que cortavam o Estado de Santa Catarina no sentido 
Sul-Norte (COSTA, 1982, p. 158). Próximas a este caminho foram se formando as primeiras vilas e cidades da região e foi construída a estrada de ferro São Paulo-Rio Grande. Neste período, João Maria usava um hábito franciscano e seu abrigo era uma cavidade no penhasco donde brotava água pura e fria. Este local, chamado de Pedra Santa, aos poucos, foi tornando-se um centro de peregrinações, a gruta logo foi considerada santa e a água, milagrosa (CABRAL, 1979, p. 109; FACHEL, 1995, p. 16).

Após seu desaparecimento de Sorocaba, para onde teria voltado por duas ou três vezes, João Maria teria reaparecido no Rio Grande do Sul, em Santa Maria da Boca do Monte. É possível que, sua fama tivesse chegado antes que ele próprio, por meio das conversas entre os tropeiros que o haviam conhecido. Ao relatar a história do município de Santa Maria, João Belém (apud CABRAL, 1979, p. 117; FACHEL, 1995, p. 19) relata a chegada do monge ao Campestre, situado a cerca de nove quilômetros de Santa Maria. Ele diz que isso aconteceu em maio de 1846, "exatamente no dia em que nasceu um menino, para o qual o seu pai the deu o nome de João Maria da Rosa, em homenagem àquele homem santo, que àquelas plagas chegava, levando no coração a fé e nos lábios a palavra de Deus."

Acrescenta Belém (apud CABRAL, 1979, p. 117) que "não tinha ele, ao chegar, a imponência audaz de um general romano, mas a humildade serena dos mártires da fé. Entretanto, chegou, viu e venceu." Mas nem todos pensavam assim. Após ter proferido um sermão na capela, com o consentimento do vigário José Soares de Mendonça, o Pe. Vicente Zeferino Dias Lopes teceu sobre esse homem que vestia hábito preto e era conhecido como monge, o seguinte comentário: 'subindo ao púlpito profanou o lugar santo e usando uma linguagem desaforada desacatou as famílias presentes, dirigindo-lhes palavras grosseiras [...]' e, 'ao sair da igreja o monge recebeu, do então Tenente-Coronel José J. Andrade Neves, umas bengaladas em remuneração a tanto arrojo" (FACHEL, 1995, p. 22).

Fachel (1995, p. 24) afirma, também, que no Cerro do Campestre, onde João Maria fez sua morada, havia uma fonte de água cristalina, da qual os fiéis, especialmente os enfermos, se utilizavam acreditando que seriam curados ou aliviados de seus males. Deste lugar, também chamado de Cerro de Santo Antão e depois também de Cerro do Monge, situado a 300 metros de altura, João Maria só descia para pregar extensos sermões, onde merecia maior espaço a Palavra de Deus e a necessidade de penitência. Próximo de 
seu pobre rancho foi construída uma pequena capela, cujo padroeiro ficou sendo Santo Antão. E uma imagem deste santo, que o monge foi buscar na região das antigas Missões Jesuíticas, foi colocada sobre o altar. Na encosta desse morro, o monge organizou uma espécie de via sacra com dezessete cruzes, onde muitas pessoas, ajoelhadas, diariamente rezavam o terço e, após isso, ouviam os seus sermões. Aquele lugar logo se tornou um verdadeiro espaço sagrado onde se reuniam, diariamente, centenas de doentes e fiéis, vindos de centenas de quilômetros de distância, para rezar, procurar consolo e curas, e fazer preces ou agradecimentos a Deus e ao próprio João Maria. O número de pessoas, que não tinham outra esperança senão aquela, crescia dia após dia. Formavam verdadeiras romarias à procura da água milagrosa e também do barro santo, usado na cura de feridas entre outras mais.

Descontentes e inconformados com tudo o que por lá acontecia, a primeira providência, tomada pelo General Andréa, por meio da lei 141, sancionada em 18 de julho de 1848, foi mandar um médico de confiança ao Campestre para examinar as propriedades medicinais e os efeitos terapêuticos das águas denominadas santas, e procurar conhecer seus princípios. O médico enviado foi Thomaz Antunes de Abreu (apud FACHEL, 1995, p. 80), cujo relatório apresentado ao General Andréa, em 25 de maio de 1849, afirma ter encontrado, durante o período de 4 meses, cerca de mil doentes que, ocupando-se com 20\% dos mesmos e os observando atentamente, depois de um longo relato, ofereceu a seguinte conclusão: "treze se restabelecerão, cinquenta e um obtiveram melhoras [...], cento e trinta e três longe de melhorarem ficarão no mesmo estado, tornando-se piores muitos deles, e três sucumbiram." Depois disso o médico reivindicou para a sua categoria profissional o poder de medicar, a fim de curar enfermidades e também sugeriu que os doentes não mais procurassem lunáticos em vista da cura de que precisassem. Conforme afirma Felicíssimo de Azevedo (apud CABRAL, 1979, p. 121), os que para lá se dirigiam eram:

Doentes de todos os tipos e moléstias [...] gente que não tinha probabilidade de cura e gente que não tinha possibilidade de procurar médico [...] gente sem haveres para custear tratamentos - ou que não via outra maneira de se livrar da enfermidade senão apelando para o sobrenatural [...] gente sem outra esperança senão aquela [...] Muitos se sentiam aliviados, outros curados (alguns inclusive imediatamente). Outros mais, voltavam como chegado haviam. 
Como as águas não possuíam "qualquer propriedade medicinal ou terapêutica", o povo, sabendo dessa avaliação, mais ainda passou a crer que quando uma cura acontecia, o que acontecia era na realidade um milagre (CABRAL, 1979, p. 129). Isso gerou uma irritação ainda maior no General Andrea que, crendo que o monge não tinha a aprovação da Igreja Católica e temendo aglomerados ou concentrações de gente em torno de um monge, resolveu prendê-lo e o proibiu de curar ou fazer prédicas; remeteu-o "de presente" para Santa Catarina, e por ser essa "uma medida de polícia", pediu que não mais o deixasse voltar à província do Rio Grande do Sul.

O general Antero, então presidente de Santa Catarina, ficou muito contrariado com o presente recebido, e, ao perguntar ao monge para onde queria ir, manifestou que gostaria de ir à ilha do Arvoredo, que fica a 15 quilômetros do litoral de Porto Belo/SC (CABRAL, 1979, p. 128). Os pescadores que para lá o levaram, voltaram contando a todos que o monge milagroso lá se encontrava e que tinha descoberto uma água santa, que servia para curar toda a sorte de ferida. Logo, também ali, uma grande procissão o procurava. Não se sabe quanto tempo ficou na ilha, nem como saiu dela e para onde foi, mas acredita-se que ele voltou a Sorocaba ou foi deportado para o interior do Rio de Janeiro ou, ainda, que ele fugiu para Botucaraí/RS depois de ser perseguido (FACHEL, 1995, p. 30; CABRAL, 1979, p. 129).

Neste período há indícios de que ele teria estado novamente em Sorocaba e, em seguida, por volta de 1851, dirigiu-se às proximidades da cidade da Lapa, então Vila do Príncipe, ex-Capão Alto, no Paraná, tendo escolhido também ali uma gruta para abrigar-se. Sua permanência na Lapa também não foi demorada, o suficiente para se tornar conhecido na região. Neste local, ele teria feito sermão na Igreja Matriz da cidade (SOBRINHO, 1956, p. 131). João Maria, a par de prescrições religiosas, também dessa gruta, receitava a água que dela corria para todas as enfermidades e para todas as queixas. E, como sempre, em toda parte haviam os que saiam reconfortados e os que saiam curados, os que se viam recuperados e os que desciam esperançados, aumentado, cada vez mais a afluência de crentes e a reputação dos poderes sobrenaturais do monge.

Ele sempre mantinha os seus hábitos de ascetismo. Nada aceitava, salvo algumas ofertas de alimentos, tais como frutas e leite. Quando a ele deixavam outros alimentos ou dinheiro, se não os recusava de imediato, distribuía-os aos pobres, logo depois. A sua voz, também aqui, nas noites calmas, era ouvida cá em baixo, muitas vezes, chegando aos ouvidos do povo que se 
edificava na sua piedade (CABRAL, 1979, p. 133). Joaquim Borges (apud CABRAL, 1979, p. 135) afirma que o monge teria chegado nesse local em 1845, vindo de São Paulo (Tatuí) a pé. Ao prosseguir viagem, após pousar, acompanhado por um dos seus parentes, Joaquim fala que "a João Maria foi cedido um cavalo, para levá-lo até a cidade da Lapa, cavalo este que mancava." Ao voltar para a fazenda, entretanto, o cavalo que transportara o peregrino, chegou curado. Existem inúmeras histórias de curas e milagres atribuídos a João Maria (TOMAZI, 2005, p. 278), mas não há como abordá-los nesse artigo.

A gruta do monge é, ainda hoje, um lugar misterioso, de oração e também um Parque Turístico, visitado por muitas pessoas. Sobre essa gruta diversas histórias são contadas e recontadas de geração em geração (OLIVEIRA, 1992, p. 123). Uma das pedras que servia de cama do monge foi adaptada tornando-se um altar onde se fazem cultos, missas e outras celebrações ou cerimônias diversas. No interior desta gruta tem uma grande quantidade de muletas, roupas, velas e retratos daqueles que imploraram e conseguiram graças "do monge" ou "por intermédio" dele (MIRANDA, 1987, p. 1).

Depois deste pouco tempo de parada na Lapa, afirma-se que João Maria esteve em Rio Negro/PR, Mafra/SC e Canoinhas/SC, entre outros lugares circunvizinhos. Há registros da sua presença em Rio Negro (do lado catarinense, atual Mafra), em 1851. Sua parada em Mafra, e região próxima, também foi de curta duração. Segundo Cabral (1979, p. 139), após sair dali "que caminhos tomou ninguém sabe. É provável que tenha se embrenhado pelas matas, indo sair em Lages". João Maria teria voltado para Sorocaba, entre os anos 1865 e 1870, onde viveu mais algum tempo e desapareceu.

Quanto à sua morte, existem várias versões. Uma delas é que o monge teria morrido na sua própria gruta em Sorocaba/SP, atacado por algum animal feroz ou por algum desalmado. Aloísio de Almeida acredita que o monge teria ficado até 1870 em Sorocaba e depois rumou para os sertões de Araraquara, onde então, teria morrido pelo ano de 1889, ou pelo ano de 1907, segundo Hemetério Veloso da Silveira (apud CABRAL, 1979, p. 140). Outras suspeitas afirmam que, depois de ter passado por Lages, ele teria voltado para a Lapa e terminado seus dias em Ponta Grossa/PR ou que seu corpo está enterrado em Campos Novos e há ainda uma versão, que parece a mais provável, de que fora assassinado em Lagoa Vermelha/RS, em 1893 (FACHEL, 1995, p. 35; NAPOMUCENO, 2003, p. 68). Enfim, misteriosamente, desapareceu, praticamente sem deixar vestígios de sua morte. Existe ainda um entendimento, 
na região do Contestado, que ele encontra-se encantado no Morro do Taió, situado entre os municípios de Itaiópolis/SC e Santa Terezinha/SC, lugar onde ele desejava encerrar sua peregrinação (VINHAS DE QUEIROZ, 1977, p. 63; TOMAZI, 2005, p. 145).

Otacílio Costa (apud CABRAL, 1979, p. 138) acreditava que, por volta de 1862, foi erguido, na cidade de Lages, o cruzeiro de João Maria. Ele comenta:

E um dia, como um fantasma, filho da própria floresta, aparecia um velho de barbas intensas, pés maltratados, dentro de alpercatas de couro cru, um barrete de pele de tigre na cabeça, uma sacola às costas, um velho livro de orações, um cajado na mão, curvado ao peso dos anos e das caminhadas longas. Não dormia nas casas, recusava o colchão e o travesseiro e, para alimento, cozia umas ervas. [...] Ali no alto da Santa Cruz, ele convidou o povo a erigir uma cruz, como sinal da fé e marco da sua passagem por estes sertões impérvios.

Por fim, vale destacar um último documento, oferecido pelo padre Pauwels (1933, p. 199-201), que fala da morte e as últimas palavras do monge. Com algumas variações, este texto pode ser encontrado também em Fachel (1995, p. 35) e em Cabral (1979, p. 142):

Acabo de receber do povoado de Tacurú, no Chaco Papaguaio, uma carta assinada por Dom Juan Sentú Gonzales, na qual comunica que a 12 de março de 1928, à margem esquerda do Rio Pilcomayo (na República do Paraguai), entregou a alma ao Criador o mui santo João Maria d'Agostini, na avançada idade de 115 anos. Conservou sua integridade e suas faculdades mentais até o último instante e estas foram as suas últimas palavras: "dizei aos povos do Sul do Brasil que não esqueçam os conselhos que lhes dei, que sigam o caminho de Deus e plantem o trigo, a mandioca e cultivem as abelhas, porque não está longe a era de misérias, peste e doenças [...]. A democracia surgirá triunfante e a oligarquia será esmagada como uma peçonhenta víbora. Daqui a 150 anos surgirá um homem que será o enviado de Deus. Espantará os povos e atrairá a simpatia das nações, congregando todos os países da América do Sul num só País e opondo a Nação LatinoAmericana ao impulsivo desejo de conquistas e de expansão dos norteamericanos, que nesta época estarão esgotados os seus recursos, carbonizados nas forjas gigantescas das suas cidades[...]." 


\section{Santidade e missão}

Há pouca documentação sobre João Maria. Existem poucos registros históricos para falar de um personagem que marcou profundamente com suas ações, palavras e maneira de ser, a cultura popular do Contestado. Na última década do século XIX e início do século XX, no início da república, quando crescia o poder dos latifundiários e dos grupos políticos locais, os quais submetiam duramente a população rural do país, surgiram diversos movimentos de caráter messiânico, também acusados de monarquistas, liderados por beatos ou monges, considerados penitentes, curandeiros, místicos, conselheiros, para os quais afluía um número cada vez maior de pessoas. Estes movimentos se destacavam por pretenderem, entre outros aspectos, remediar problemas sóciopolíticos de variada ordem. E como isso preocupava as autoridades, estas, por sua vez, promoviam conflitos e até mesmo guerras contra tais movimentos (AURAS, 1995, p. 48; QUEIROZ, 1977, p. 352).

João Maria, a cada lugar que chegava, logo era visto por muitos como um inspirado ou um enviado de Deus, um santo. Porém, ele próprio não se apresentava como um santo, nem trazia novas doutrinas, não propunha uma palavra de subversão, mas o próprio evangelho e a doutrina da Igreja, inculturados; ia consolando, levantando cruzes pelos caminhos e cimos elevados, recomendando a caridade, as rezas e, num teor apocalíptico, previa castigos e flagelos para a humanidade. Procurou ser um apóstolo humilde que não ameaça, mas aconselha, que não se rebela, mas se humilha, que não comanda, mas serve (CABRAL, 1979, p. 124). Andando sozinho e a pé, percorreu, por algumas idas e vindas, todo o planalto catarinense, o sul e o sudeste brasileiro; de povoação em povoação, abrigando-se nos bosques, nos grotões ou dormindo nos ranchos abandonados, recusando esmolas, só aceitando, de vez em quando, algum prato de comida, pois se acostumara a uma alimentação natural, constituída de ervas, frutas e pinhão (AVILA DA LUZ, 1999, p. 138).

Ávila da Luz (1999, p. 139) relata que a fé dos sertanejos por João Maria era imensa. Quando o monge chegava, o povo da redondeza logo acorria ao seu efêmero pouso, e aí, à noite, ao calor e à luz de uma fogueira, acompanhavam-no em suas orações, que às vezes se transformavam em longos e solenes "terços". O lugar onde o monge fazia momentaneamente sua pousada, geralmente debaixo de uma árvore ou junto a um córrego ou "olho d'água" que benzia ao partir, continuava a ser motivo de romaria. A água abençoada, as 
cinzas que restavam das fogueiras, misturadas com água, eram tidos como remédios infalíveis para muitas doenças. Esse lugar normalmente era protegido com algum tipo de cerca e nele levantava-se uma cruz pelos crentes. Tudo se impregnava de sua santidade.

Como crescia a cada dia a fama de santidade de João Maria ou pelo fato de somente ele "ter grande autoridade" naquilo que falava, sendo ouvido atenciosa e respeitosamente e mesmo venerado pela grande maioria do povo da região, as autoridades começaram por averiguar sua sanidade mental, questionar seus ensinamentos, suas atitudes e práticas religiosas e, ainda, manifestaram-se sobremaneira incomodadas com seu caráter profético e com seus questionamentos em relação aos rumos da política, da economia e da sociedade. Assim, estas autoridades passaram a divulgar a ideologia de que também o próprio povo, devoto ou seguidor de João Maria, estava possuído por um grande leque de superstições, misticismo, crenças absurdas e infantis, esquizofrenias, símbolos, ritos e danças exóticas ou esquisitas, entre outras coisas que estavam prestes a desaparecer com o advento da racionalidade científica e da modernização.

Mesmo não estando presente na guerra do Contestado, a João Maria também foi atribuída a responsabilidade e o próprio comando da guerra. Paradoxalmente, mesmo desprezando a força da mística e o valor da religiosidade popular, as elites intelectuais, religiosas e militares entenderam que a influência e o poder dessa liderança religiosa foram grandes. Frei Stulzer (1982, p. 31) entendeu que João Maria:

[...] parecia, aos olhos dos simples, um enviado de Deus e o povo o venerava como se fosse um santo [...]. É expressão usual do sertão: "se Deus quiser e nosso São João Maria". É supérfluo penetrar nos grandes males que à Religião causou esse João Maria. A Guerra dos fanáticos só foi possível na fé àquele mensageiro. Uma palavra de sua boca valia, e vale ainda hoje, mais do que as verdades eternas do Evangelho, do que quaisquer instruções de sacerdotes e bispos, e até o santo padre só acerta ensinar a verdade, se esta confere com a pregação de João Maria.

João Maria peregrinava por esta região levando à população palavras de alerta, ânimo, conforto e esperança. Não pretendia conduzir o povo a uma espécie de fanatismo religioso, mantinha distância das vilas e cidades, preferindo apenas o contato com pessoas nos distantes sertões, onde os assistia em suas 
necessidades, caso fosse solicitado. Não usava armas, era pacífico e jamais admitiu ou induziu os caboclos do Contestado a práticas de violência (TOMAZI, 2005, p. 356). Foi o seu modo de pensar, sentir e agir que influenciaram a população da região, que já era a priori messiânica e mística.

Queiroz (1977, p. 269) cita-o como sendo aquele que "destacou-se pela persistência de sua pregação, pelo sucesso que obteve, pela grande área que sua fama cobriu e na qual, até hoje, é reverenciado como um santo [...] peregrinava (de Ipanema) para o sul erguendo capelas e cruzeiros, pregando, curando, organizando procissões [...]."

João Maria não foi apenas um "monge" ou um homem religioso no sentido estrito do termo. Não foi apenas um homem do "sagrado". Ele foi um homem que se preocupou com várias dimensões objetivas e subjetivas da vida humana. Por mais que pregasse a conversão, chamasse para a oração e a penitência, ele não separava a dimensão "profana" da "religiosa" da vida; ao contrário, ele as integrava dando-lhes um sentido (MONTEIRO, 1974, p. 176). Valle (apud BRITO; TENÓRIO, 2001, p. 76), ao fazer uma análise psico-social dos líderes messiânicos do Brasil, afirma que estes "integram em si a chefia profana e a chefia religiosa de suas comunidades."

As pessoas não precisavam sair de seu mundo para experienciar a mensagem dele, ao contrário, ele se dirigia ao seu mundo e lhe dava um sentido. João Maria carregava consigo um oratório, que Frei Rogério denominou de "caixinha" (VINHAS DE QUEIROZ, 1977, p. 51), no qual afirmava estar presente o próprio Deus, expressando assim que o eixo de sua missão era de caráter religioso. A vida material continha e era alimentada pela dimensão espiritual, e esta contemplava a preocupação com a dignidade humana, a ecologia, a terra, as plantações, o gado, a erva-mate, os negócios.

João Maria aceitava a reunião de pessoas em torno de si somente em momentos de oração como de novenas e terços, onde também oferecia uma mensagem, que podia chegar a longas homilias, a partir de textos bíblicos e do conhecimento da realidade circundante (QUEIROZ, 1977, p. 269). Ele não gostava de ficar muito tempo em um mesmo lugar e nem de ser seguido no caminho. As pessoas com as quais dialogava ou pelas quais rezava sentiam-se abençoadas, agraciadas, curadas, protegidas e animadas para a vida, fortalecidas em meio a tantas adversidades e sofrimentos, decorrentes das intempéries, das ações perversas de coronéis, colonizadores, governantes, entre outros. 
Miranda (1987, p. 04) soube da existência do profeta João Maria, em começo do ano de 1896, quando a sua fama começou a se divulgar pelos povoados de União da Vitória. Segundo Miranda, seu estilo era o de um grande pecador que procurava, no arrependimento e no bem que fazia, remir as suas culpas anteriores. Diz ainda, que ele era um bom homem, caridoso e moderado, apenas imbuído de espírito divino e com idéias monárquicas. Seguindo o pensamento de Miranda, Belém (apud CABRAL, 1979, p. 123) diz que João Maria se tornou:

[...] o guia, o inspirador, o conselheiro do povo que parecia a espera de alguém que lhe alentasse a crença, periclitante à falta de uma palavra ungida de fé cristã. Não era um sacerdote culto, encarregado de propagar a doutrina de Cristo. Era um indivíduo de poucas letras, cuja monomania religiosa o arrastava através de montes e vales, levando aos doentes, aos pobres, aos deserdados da fortuna, a resignação para os sofrimentos, a esperança de melhores dias, cultuando a fé que remove montanhas. [...] E João Maria foi considerado Santo.

João Maria preenchia certo vazio, sob o ponto de vista religioso, pois praticamente não havia lideranças religiosas, ordenadas ou consagradas pela Igreja, para atendê-los oferecendo-lhes consolo, estima, uma mensagem de esperança e de sentido às suas vidas, respondendo aos seus anseios, e sendo para eles consolo e apoio diante das suas dores, angústias, conflitos, pobreza e morte.

Ao que parece não havia uma ruptura total entre o clero católico e João Maria. Essa ruptura é um tanto quanto relativa. João Maria foi chamado de "lobo com pele de ovelha", mas também teve a permissão de fazer sermões em diversas igrejas (MACHADO, 2004, p. 173). Diversos sacerdotes entenderam que ele possuía certo conhecimento do evangelho e que seu trabalho era útil para atingir positivamente as almas dos sertanejos. Viram que o seu trabalho não era exercido em oposição ao da Igreja Católica. O sacerdote e historiador Aloísio de Almeida, de Sorocaba, escreveu a Cabral uma longa carta, onde menciona que seu exercício não assumia "as funções reservadas aos clérigos ordenados" (VINHAS DE QUEIROZ, 1977, p. 50) e que "buscou a solidão e não o atraíam as glórias do mundo. Quando a multidão o cercava, sumia-se [...]. Vivia interiormente para a contemplação e para a prece" (CABRAL, 1979, p. 143). 
Frei Rogério de Neuhaus, o mais afamado e reconhecido sacerdote católico da região, nos tempos do Contestado, nas suas Reminiscências (TOMAZI, 2005, p. 160; SINZIG, 1939, p. 153-158), nos oferece "alguns esclarecimentos sobre um homem João Maria d'Agostini”. Ele, julgando ser um dever fazê-lo, assim descreveu amplamente João Maria e a conversa que teve com ele, em 1897, em uma das comunidades da paróquia de Lages. Entre as várias considerações citadas está "andava ele a pé, com uma malinha às costas, [...]. Receitava alguns remédios. O povo tinha grande fé nele. Muitos o veneravam como santo." Ele era convidado para batizar e ser padrinho de grande parte das crianças que nasciam na região. A conversa não foi muito amigável. Falaram de penitência, castigos e mandamentos de Deus, velas, dias de escuridão, fim do mundo, bíblia, mortes de "bugres", batismo de crianças, confissão, missas, entre outros. Ao convidá-lo para assistir, no dia seguinte, à santa Missa, em casa do Vuca. João Maria respondeu: "se o Sr. quiser esperar até ao meio dia depois de eu ter despachado o povo, eu vou, porque muita gente quer remédios e custa despachá-los." João Maria também falou: "A minha reza vale tanto quanto uma missa!"

Existem outras versões desse episódio (ÁVILA DA LUZ, 1999, p. 145; CABRAL, 1979, p. 111). Sendo que a mais original é a das Reminiscências, na qual Frei Rogério ainda acrescenta: "Infelizmente sempre há gente que parece ter mais fé num João Maria, do que em Deus mesmo [...]. Muitas pessoas simples aceitam antes uma mentira que julgam ser de João Maria, do que um conselho da boca do padre, que é ministro do Senhor."

O que se percebe neste diálogo é que aparecem tanto manifestações de incompreensão e estranhamento, como também de respeito, interações, trocas e acomodações recíprocas. Frei Sinzig, ao descrever esta narrativa, conclui afirmando que, da parte do Frei Rogério, "não foi necessário tomar uma atitude que exigisse coragem, mas, de fato, como se vê por entre as linhas, o fanatismo do povo era tão grande, que havia perigo em dizer uma palavra que pudesse melindrar o ídolo." Logicamente que o fato de este monge batizar, dizer que sua reza "valia por uma missa" e ser venerado pelo povo da região do Contestado, incomodava agentes ordenados da Igreja Católica. Realmente, este texto revela a superioridade da aceitação popular de João Maria. Percebe-se também que, enquanto Frei Rogério insiste na "ortodoxia" católica e na centralidade do poder dos agentes ordenados desta Igreja, o monge deixa-se conduzir por intuições cheias-de-fé em relação à realidade, e um temor ou uma preocupação profunda em relação ao futuro. 
Em relação à sua santificação pela cultura popular do Contestado, Ávila da Luz (1999, p. 147) lembra que João Maria, depois de “morto" ou "desaparecido", começou a exercer uma influência ainda maior "na alma crédula e fanatizada do sertanejo". As lendas começaram a nascer; os milagres operados por sua intercessão a se multiplicar; as suas pregações a ter mais vida; os patuás, invocando o seu nome, a se difundir profusamente; os cruzeiros levantados por suas mãos escarnadas, a ser objetos da devoção sertaneja. Tornou-se, enfim, por esta estranha canonização, o padroeiro do sertão catarinense: o "São João Maria!"

Em síntese, pode-se afirmar que João Maria era um homem solitário, porém com muitos seguidores, afilhados e amigos; conversava calmamente, todos o ouviam e seguiam suas orientações e conselhos, era despojado e contentava-se com o mínimo necessário, sua linguagem era repleta de metáforas e de compreensão às vezes difícil, mas que enchia de espanto e veneração os ouvintes; falava do fim dos tempos, numa linguagem apocalíptica, de tempos de desgraças, castigos e do "fim do mundo" para breve, tempos estes, em que "o sangue ia correr sobre a terra como rios", porém a todos passava uma mensagem de solidariedade e de paz. Até que ponto ele realmente teria anunciado catástrofes e a guerra que estaria por acontecer pode ser questionado, mas o que importa aqui é percebermos que a importância de sua mensagem é tamanha que, mesmo sendo, talvez, apenas algo que posteriormente fora atribuído a ele, ainda hoje isso é lembrado como mensagem ou profecia sua.

Ele sempre mantinha os seus hábitos de ascetismo. Nada aceitava, salvo algumas ofertas de alimentos, tais como frutas e leite. Quando a ele deixavam outros alimentos, aves, animais ou dinheiro, se não os recusava de imediato, distribuía-os aos pobres, logo depois. Qualquer presente que lhe fosse oferecido, tudo era rapidamente distribuído. Ele nada possuía em termos de bens materiais, apenas carregava consigo alguns utensílios indispensáveis para viver, cultivar a sua espiritualidade e manter-se na missão. Ainda hoje, continua sendo lembrado como quem foi capaz de fazer o bem, trazer consolo aos doentes, esperança aos desesperados, paz aos angustiados, estima aos desprezados, reconhecimento aos esquecidos, remédios aos doentes, sabedoria aos incultos, coragem aos fracos, solidariedade aos empobrecidos e maltratados.

Era humilde e por isso respeitado e estimado por todos. Ninguém ousava criticá-lo. Identificou-se com os mais pobres e oprimidos e os elevou em termos de respeito, reconhecimento, dignidade e estima. Não deixava de advertir contra os erros e as injustiças que via (apud FACHEL, 1995, p. 50), 
Ângelo Dourado, que teria conhecido pessoalmente o monge, afirma que ele "é um tipo especial que convém ser conhecido. Ele conversa com os moradores sem ostentação, sem impostura, sua conversa é calma, como quem fala para si só, porém todos o ouvem, todos lhe obedecem; sua figura é humilde, porém todos o respeitam e estimam." Ele disse, ainda, que o monge procurou-o e pediu para tocar com sua bandeira os feridos com os quais se ocupava fazendo curativos, quando então este a cedeu de boa vontade dizendo que sabia que ele advogava a nossa causa, quanto então o monge respondeu que "não era por nós, mas pela justiça é que Deus mandou que se sofra com os que sofrem."

Enfim, entre os descendentes do Contestado não há notícias de que João Maria morreu. Ele permaneceu no coração dos excluídos, explorados e desprezados de uma grande extensão do sul do Brasil. Foi um profeta ou um santo e curandeiro ao qual o sertanejo do Contestado demonstrou e ainda demonstra afeição, carinho, respeito e devoção. Sua memória não foi destruída e suas fotos permanecem praticamente intactas, "ao lado" ou "acima" de imagens de outros santos católicos, em muitas casas. A santidade de João Maria, que noutros tempos foi visto como "ignorância religiosa", na atualidade é generalizadamente aceita, inclusive por sacerdotes e bispos da Igreja Católica. Na sua religiosidade, hoje, os homens e mulheres, especialmente os mais velhos, mas também os jovens, defendem, senão a santidade do monge pelo menos a relevância de sua mensagem profética e até mesmo revolucionária.

É verdade que João Maria não defendeu grandes projetos de transformação social, mas sim a busca de novas maneiras de viver e se relacionar com os demais, a partir do cotidiano. Ele é lembrado, não como alguém que almejasse derrubar a república, os coronéis ou o imperialismo norte americano que se alastrava na região, mas sim, como alguém que, por valorizar a mística e o modo caboclo de vida, foi capaz de provocar grandes mudanças na mentalidade e no coração do ser humano e também na sociedade, por consequência. Com ele a comunidade cabocla sentiu-se reconhecida, passou a ter mais autoestima e a compreender a riqueza do seu próprio modo de vida, dos seus costumes, das suas crenças e exigir respeito. Isso não significa que a população acomodou-se com o seu modus vivendi. Ao contrário, maior ainda se tornou o desejo de mudança. Especialmente porque a realidade sócioeconômica e política em que se encontravam eram insuportáveis: a expropriação de suas terras, o desemprego, a exploração, a dominação coronelista, o abandono por parte dos poderes governamentais, entre tantos outros fatores, a tornavam assim. 
São João Maria passou a integrar o rol dos santos mais venerados pelos caboclos da região, inclusive sendo invocado nas rezas de terço e nas ladainhas pelos 'puxadores de reza', ao lado de São Sebastião (MACHADO, 2004, p. 72), de São João dos Pobres, de São Gonçalo, de São Benedito, de São João Batista, entre outros (THOMÉ, 1997, p. 56). Aliriano A. da Silva, entrevistado por Tomazi (2005, p. 172), chegou a considerar que: "pra falá a verdade, Jesus deixou São João Maria no lugar dEle.” Fredericindo M. de Souza (apud THOMÉ, 1997, p. 58), ao falar de João Maria, lembra que:

[...] sua existência cobriu-se com o manto da lenda, do mistério e do romance, na voz do povo, nas trovas dos violeiros, nas prosas ao pé do fogo, nas rodas de chimarrão. De boca pra fora é o seu João Maria, mas em seu coração, lá no íntimo, arredado da curiosidade incrédula de estranhos, no altar da sua fé, é o São João Maria.

\section{Mensagem profética}

Segundo Gallo (1999, p. 177), "o profeta é, antes de mais nada, um interprete." A profecia de João Maria não era simplesmente uma espécie de visão misteriosa sobre acontecimentos futuros, mas sim algo que brotava de uma observação, uma vivência e uma reflexão profunda da realidade em que se encontrava, para somente então, assinalar para certas tendências e possibilidades, em relação ao rumo da história e a vontade de Deus. É possível afirmar que ele "não dizia muito mais do que as pessoas queriam ouvir" ou que ele "falava de acordo com o sentir do povo" (SINZIG, 1939, p. 154; STULZER, 1982, p. 31) e também que, de certa forma, ele soube interpretar o "espírito de seu tempo".

Por mais que João Maria não tenha sido julgado revolucionário, moderno ou pós-moderno, nem conservador ou reacionário, sua mensagem, necessariamente, tem uma conotação política. Não há neutralidade política em qualquer discurso, por mais religioso ou teológico que se apresente. Por mais que ele declarasse aversão ao governo republicano (QUEIROZ, 1977, p. 270) e uma opção clara pelos pobres, não há notícias de que ele tivesse feito um corte de classes em seu discurso. Sabe-se, porém, que muitos membros da classe dominante ficavam inquietos com a sua presença. Algumas vezes o toleravam, outras o perseguiam. Pelo fato de que alguns monarquistas tentavam manipular os 
descontentamentos do povo contra a nova situação política, qualquer manifestação de descontentamento de massa, passava a ser tachada de monarquista e era reprimida com violência. É nesta situação de crise, descontentamento e lutas que surge a campanha federalista no Sul, que irrompe a campanha de Canudos, na Bahia, e o movimento do Contestado, no Sul. Afirma-se que no Contestado, grande parte do povo logo assumiu, com João Maria, a causa da monarquia. Porém, por mais que pareça, não se pode afirmar que se buscava o retorno da monarquia enquanto sistema de governo, e sim uma monarquia utópica e sagrada: "a lei de Deus". João Maria declarava que a monarquia era a "lei de Deus" e a república a "lei do Diabo". De qualquer forma ele, de fato, criou uma aversão à república. E isso favoreceu para que fosse colocado na boca e no discurso de líderes do Contestado que, além de buscarem o Reino de Deus, também participavam de uma campanha política de caráter monarquista e antirrepublicana (TOMAZI, 2005, p. 175). Atribuiu-se a ambos os monges severas críticas contra a república, por mais que, em alguns momentos isso se parece mais como forma de legitimar a guerra e o massacre dos habitantes do pré-Contestado, facilitando assim a execução do plano de "limpeza da área" em favor das empresas de colonização e dos coronéis que dominavam a região e queriam ampliar seus latifúndios ou vendê-los para os "gaúchos" e/ou euro-descendentes que pretendiam adquirir terras e habitar em Santa Catarina (TOMAZI, 2005, p. 61).

É importante relembrar que, com o advento da república, os prejuízos para o povo caboclo do interior do país foram consideráveis. Um deles foi o fato de que suas terras, ou seja, as terras de que seus antepassados se haviam apossado, passaram para o controle dos Estados e, assim, em muitos casos, deixaram de ser suas. As terras devolutas, de que a União se despojou em favor dos Estados, a partir de 1891 as deixou também sem proteção legislativa e abandonadas. Sendo assim, novamente, à semelhança do Tratado de Tordesilhas, foram sendo passadas, por meio de concessões dos governantes, a grandes coronéis e latifundiários ou "grileiros" diversos, conforme lhes convinha eleitoralmente ou por conta de outros interesses. Assim mesmo, é possível afirmar que a questão da propriedade das terras não tenha sido a questão central que fez desencadear a guerra. Mais do que o valor material da terra, para os caboclos e especialmente para os seus "pais" indígenas, o maior valor da terra é o simbólico. A terra não é para eles tão somente um meio de produção a ser disputado ou uma fonte de subsistência, mas o lugar onde estão sepultados os ancestrais, os irmãos mortos. Para eles, a terra e também as matas possuem alma, espírito. É como uma mãe que acolhe a todos os seus filhos e não permite que 
algum deles seja excluído de seu seio. É o mesmo solo onde os inimigos de seus filhos sequer devem ser nela enterrados. Se não são seus filhos, também não serão bem vindos no seu seio. É uma terra sagrada (MONTEIRO, 1974, p. 49).

Outro aspecto considerável, presente no movimento do Contestado, foi a luta anti-imperialista. Foi encontrado, no bolso de um caboclo morto em um combate, em Calmão, um trecho legível que diz: "O governo da república toca os filhos brasileiros dos terreno que pertence a nação e vende para o estrangeiro, nós agora estemo disposto a fazer valer noço direitos.[...] Nóis não tem direito de terras, tudo é para as gentes da Oropa" (D'ASSUMPÇÃO, 1917, p. 245; STULZER, 1982, p. 42). A partir disso, podemos entender a guerra do Contestado como protesto, resistência e luta pela sobrevivência de um povo em vias de ser massacrado.

Mais do que uma mensagem política, no sentido estrito do termo, talvez João Maria tenha deixado uma mensagem em defesa da ecologia. Mais do que defender ou condenar a monarquia ou a república, João Maria preocupava-se com a vida do ser humano num sentido amplo. Para ele, a natureza era regida pelas suas próprias leis e estas deveriam ser respeitadas, pois as considerava sagradas. Entendia que a natureza era como um corpo humano. Caso algo desse corpo fosse desrespeitado, todo o corpo padeceria, vingar-se-ía ao ser agredido, provocando calamidades e destruição. O interesse central da missão de João Maria não era propriamente defender a natureza em si mesma, mas sim defendê-la para que o ser humano daquela geração, e também das gerações vindouras, pudessem aprender "as leis da natureza", respeitá-las e procurar adaptar-se a elas sem destruílas, pois as mesmas teriam sido estabelecidas pelo próprio Deus. Ele sabia que o problema não estava na natureza, mas em como o ser humano poderia viver melhor nela. É realmente interessante esse "tratado de ecologia" atribuído a João Maria. Quando há cerca de um século, avançavam as idéias baseadas no mito do progresso e da ciência, dentro de uma filosofia positivista e utilitarista, aparecer um texto que liga religião, ética e ecologia e é assumido por muitos que o conheceram, praticamente como um texto sagrado, por entenderem ter sido escrito "diretamente" por São João Maria, é realmente algo precioso. Nesse tratado existem 29 "mandamentos" que, segundo Felippe (1995, p. 36), seria uma espécie de manual do santo. Nele, temos: "O que a terra dá emprestado, quer de volta"; "A terra é nossa mãe. A água é o sangue da terra-mãe"; "Pai da Vida é Deus. A mãe da vida é a terra. Quem judia da terra é o mesmo que estar judiando da própria mãe que o amamentou." 
Além de apontar para valores religiosos e princípios éticos a serem respeitados por todos, ele insiste no cuidado para com a terra, a água, os animais e toda a natureza, enfim, no cuidado para com a vida humana e a de toda a Criação. Não é demais afirmar que, em muitos aspectos da vida e dos costumes dos caboclos e caboclas do Contestado e de seus descendentes, eram os ensinamentos de João Maria que serviam como parâmetros para julgar se deveriam ser aprovados ou desaprovados, respeitados ou rechaçados. Os valores humanos bem presentes na mensagem de João Maria são: o respeito, a defesa da vida, da honra, da sinceridade, da lealdade, a importância do equilíbrio, a prevenção contra crimes, assim como o valor da verdade e da justiça. Ele considera a importância e a necessidade de valores morais e éticos, herdados da tradição cultural e religiosa.

João Maria insistia no cuidado para com as matas e animais e atribuía um valor especial para as fontes e nascentes de água. Um dos aspectos da natureza que ele mais valorizou foi a água da fonte, a água das nascentes, a água que nasce na rocha, a água fresca, limpa e cristalina. A água era, para ele, um símbolo sagrado e, além disso, era também um remédio usado para curar muitas pessoas das mais diferentes enfermidades. Era por meio da água pura, ou, quando muito, misturada e fervida com algumas ervas medicinais, que o Cristo sofredor se voltava para o enfermo e o curava (TOMAZI, 2004, p. 187). Enfim, pode-se concluir que João Maria pregava uma antiga e nova experiência espiritual com relação à natureza, à água e aos seres vivos.

A dimensão profética da mensagem de João Maria é lembrada por muitos descendentes do Contestado e o respeito por sua pessoa é uma atitude irrenunciável de todos quantos, no Contestado, procuram valorizar a memória e a cultura dos seus pais. A religiosidade do Contestado é portadora de uma esperança profética, por isso os seus descendentes, mesmo submetidos, ainda hoje, a regimes de semiescravidão, esforçam-se por não desesperar e por não aceitar a hipótese de que a realidade presente tenha a última palavra. E, no meio de tanta perseguição, repressão, dominação, conquistas, o que sobreviveu no seio dessa religiosidade, merece respeito e consideração.

Enfim, vale afirmar que ele também, como Marx, sonhou com uma espécie de "Cidade Santa", uma sociedade livre, sem opressores e oprimidos, sem classes sociais, ecologicamente sustentável, com relações igualitárias e includentes entre os seres humanos. E, este desejo de construir uma "cidade santa", foi capaz de mobilizar muitas pessoas e até gerações. 
A religião popular latino americana é uma forma de encarar o mundo e a vida marcados pelo sofrimento e pela cruz. Diante da pesada cruz colocada nos ombros dos mais pobres emerge a profecia. A denúncia e o anúncio. Denominar a fé de um povo e as suas diferentes formas de vivenciá-la, de ignorância ou infantilidade é uma das tantas formas de conquista e genocídio.

\section{Conclusão}

A mensagem de João Maria, não se baseia fundamentalmente em conceitos e teorias racionais, objetivas e cientificamente comprovadas, mas sim em ensinamentos provindos de sua compaixão pelos que sofrem. Sua sensibilidade solidária, tornava-o capaz de compreender o ser humano, ensinálo a viver, curar suas enfermidades e, inclusive, salvar vidas.

João Maria possuía uma sabedoria e uma grande sensibilidade humana, que o fazia capaz de tocar fundo no coração humano. As palavras que ele dizia não eram esquecidas facilmente ou não eram esquecidas jamais. Seu trabalho gratuito e solidário, fazia com que muitos conflitos, dores e problemas humanos fossem solucionados ou ao menos amenizados. Sua sabedoria não consistia em proferir muitas palavras e nem em apresentar os conhecimentos mais avançados da ciência da época; baseava-se, sim, numa espécie de "intuição" cheia de fé, capaz de dar um sentido à vida e uma interpretação convincente em relação a certos mistérios ou a certas indagações que incomodavam os que o procuravam.

Esta sabedoria transmitida por João Maria aos que o conheceram foi, por estes, retransmitida aos seus descendentes. É uma sabedoria de vida que foi se acumulando e sendo ressignificada com o passar dos anos. Logo, as histórias que hoje são contadas sobre João Maria, podem não ser tão originais quanto se poderia almejar, porém, o seu valor maior consiste no "sentido" que hoje elas dão à vida dos descendentes do Contestado.

Pode-se afirmar que a sabedoria dos descendentes do Contestado foi forjada no "fogo" ou no sangue derramado; que é uma sabedoria testada em um caminho árduo e complexo, cheio de encruzilhadas, sofrimentos e sonhos ou a partir de uma "crença impossível" ou, poder-se-ia também afirmar, de uma "mística profunda" (TOMAZI, 2005, p. 270). 
João Maria captou os anseios dos deserdados e transformou-se em portavoz das angústias dos caboclos do Contestado. Aos poucos, João Maria foi sendo recebido e divulgado como um homem de Deus. Ele foi sendo associado ao próprio Cristo e aos santos e com isso continua, ainda hoje, a exercer grande influência entre os descendentes do Contestado. Suas constantes peregrinações de um lugar para outro, a renúncia aos bens materiais e certo rigorismo moral, fazem dele símbolo de um poder que se coloca acima dos homens comuns e símbolo da identidade social positiva dos pobres, dando-lhes uma nova identidade. Alexandre Otten (1990, p. 136) afirma que, "o líder religioso é de grande importância para mobilizar e canalizar as forças inovadoras do grupo", e com isso "a exclusão, que os abandonados e deserdados sofreram, se transfigura em eleição. Os deserdados se sentem como filhos de Deus, como povo eleito, chamado para uma vida nova."

Em João Maria há certa continuidade ou prolongamento da mensagem e mística cristãrrevolucionária e da não-violência. A crença de que a realidade presente não possui a última palavra e que existe um "paraíso" a ser buscado e que este passa pela edificação de uma nova sociedade justa, fraterna e solidária, estava presente na sua mensagem e na sua mística. Ele e, por meio dele, tantos outros acreditaram e acreditam que a melhor forma de enfrentar a violência e os conflitos do tempo presente consiste em não entrar no seu jogo, pois quem entra no jogo da violência, está cedendo ao seu poder e sendo devorado por ela.

Milagroso, curandeiro, profeta, benzedor, monge, peregrino, eremita, santo, pai, paizinho, enviado ou amigo de Deus, João de Deus ou simplesmente João Maria (de Agostini, de Jesus, ou de Santo Agostinho) são alguns dos muitos nomes ou adjetivos atribuídos a esse personagem mítico tido, pelos remanescentes do Contestado, como homem bom, do bem, pessoa simples, gente do povo, humilde, de pouca fala, sozinho, alguém que sabe ouvir, que fala com poder e a todos convence, que não é homem de duas palavras e anuncia o que está por vir, que se compadece dos que estão doentes ou sofrendo de qualquer mal, que tem poder sobre maus espíritos, detesta a falsidade, o orgulho, o acúmulo de riquezas, é homem pacífico, busca o governo de Deus para a terra e condena o governo dos homens, da república, e alerta para o fim do mundo e chama à conversão, ao abandono do desrespeito, da inveja, das malcriações e dos pecados.

Ainda hoje, João Maria é lembrado nos mais diversos tipos de conversas, encontros, cursos e romarias. Sua mensagem é divulgada por meio de muitas histórias, contos, metáforas, assim como, com diversos símbolos, 
rituais, imagens e monumentos. Diversas fotos deste "santo" são encontradas em algumas igrejas, grutas e em muitas casas dos descendentes do Contestado. Em torno delas, ou seja, deste santo, foi sendo construída uma mística que serve de referência fundamental para suas vidas. Muitas pessoas, ainda hoje, continuam a acreditar no poder deste santo e o veneram. Por intermédio dele, surgem e apresentam-se os milagres aqui e acolá. Além da foto do profeta e santo, existem diversos símbolos que lembram sua mensagem, pessoa e missão. São símbolos de uma realidade ausente e presente, passada e a ser resgatada. E símbolos não se limitam a um mero fenômeno reflexo de uma realidade vivida, mas são parte fundamental desta realidade e, como tal, dotados de eficácia real (QUEIROZ; VALLE, 1979, p. 55).

Ao analisar o conteúdo ou a mensagem de João Maria percebe-se que aparecem elementos de teor apocalíptico, escatológico, messiânico, milenarista, profético e outros mais. Não será possível aprofundar cada uma dessas dimensões da mensagem nesse artigo. Diversos pesquisadores já seguiram um ou outro desses caminhos. Podemos apenas apontar aqui para o fato de que tudo começou porque havia uma realidade histórica insuportável para muitos que, por sua vez, alimentavam a crença num outro mundo. Conectada à denúncia da realidade opressora em que se encontravam, aparece a profecia, cujo enfoque está na busca de alternativas e no anúncio de um novo mundo, onde haveria a vitória do bem sobre o mal, que culminaria nos mil anos de felicidade, àqueles que não se deixassem seduzir pela besta.

Enquanto durar a história, aparentemente sem sentido, tem-se que viver na contradição entre o que acontece efetivamente e a nossa esperança. A mensagem de "São" João Maria é uma dessas brasas acesas, presente na cultura e na religiosidade dos descendentes do Contestado. Ao mesmo tempo em que representa consolo diante dos sofrimentos, ela é também uma chama profética e rebelde, que não aceita a ideologia de que a última palavra da história é a realidade presente. No meio de tanta perseguição, repressão, dominação, conquistas e massacres o que sobreviveu no seio da mística do Contestado, merece respeito e consideração. A memória da mensagem de João Maria tem, bem presente, a esperança de dias melhores, de libertação e de paz, assim como uma atitude mística, não de derrota, nem de desejo de vingança, mas sim, um sentimento de irmandade, solidariedade e respeito para com os demais seres humanos e para com toda a Criação. 


\section{Referências}

AURAS, M. Guerra do Contestado: a organização da irmandade cabocla. 2. ed. Florianópolis: Ed. da UFSC, 1995.

ÁVILA DA LUZ, A. Os fanáticos: crimes e aberrações da religiosidade dos nossos caboclos. 2. ed. Florianópolis: Ed. da UFSC, 1999.

BRITO, Ê. J.; TENÓRIO, W. (Org.). Milenarismos e messianismos ontem e hoje. São Paulo: Loyola, 2001.

CABRAL, O. R. A campanha do Contestado. 2. ed. Florianópolis: Lunardelli, 1979.

COSTA, L. O continente das Lagens: sua história e influência no sertão da Terra Firme. Florianópolis: FCC, 1982. v. 1.

D'ASSUMPÇÃO, H. T. A campanha do Contestado. Belo Horizonte: Imprensa Oficial do Estado de Minas Gerais, 1917. v. 2.

FACHEL, J. F. Monge João Maria: recusa dos excluídos. Porto Alegre: UFRGS; Florianópolis: Ed. da UFSC, 1995.

FELIPPE, J. E. O último jagunço: folclore na história do Contestado. Curitibanos, SC: Universidade do Contestado, 1995.

GALLO, I. O Contestado: o sonho do milênio igualitário. Campinas: Ed. da Unicamp, 1999.

MACHADO, P. P. Lideranças do Contestado: a formação e a atuação das chefias caboclas (1912-1916). Campinas: Ed. da Unicamp, 2004.

MIRANDA, A. Contestado. 19. ed. Curitiba: Lítero-Técnica, 1987.

MONTEIRO, D. T. Os errantes do novo século: um estudo sobre o surto milenarista do Contestado. São Paulo: Duas Cidades, 1974.

NAPOMUCENO, D. V. R. História de Lagoa Vermelha, até o início do 3. milênio. Porto Alegre: EST, 2003.

OLIVEIRA, C. A. de. A construção e a permanência do mito de João Maria de Jesus na região do Contestado, Santa Catarina. 1992. 187 f. Dissertação (Mestrado em Antropologia Social) - Universidade Federal do Rio Grande do Sul, Porto Alegre, 1992. 
OTTEN, A. Só Deus é grande. São Paulo: Loyola, 1990.

PAUWELS, Pe. G. J. Contribuição para o estudo do fanatismo no sertão sul-brasileiro. Rio de Janeiro: Philologia e de História, 1933. Tomo II.

QUEIROZ, M. I. P. de. O messianismo no Brasil e no mundo. 2. ed. São Paulo: Alfa-Omega, 1977.

QUEIROZ, J. J.; VALLE, J. E. R. (Org.). A cultura do povo. São Paulo: Cortez \& Morais, 1979. (Coleção do Instituto de estudos especiais).

SAHLINS, M. Ilhas de história. Rio de Janeiro: Jorge Zahar, 1990.

SINZIG, Frei P. Frei Rogério Neuhaus. 2. ed. Petrópolis, RJ: Vozes, 1939.

SOBRINHO, Pe. J. A. Da Lapa: verdades de arrepiar. Livro Tombo da Matriz, [S.1.], n. 4, p. 92, 1956.

STULZER, Frei A. A guerra dos fanáticos: a contribuição dos franciscanos. Petrópolis, RJ: Vozes, 1982.

TOMAZI, G. A mística do Contestado: a mensagem de João Maria na experiência religiosa do Contestado e dos seus descendentes. 2005. $416 \mathrm{f}$. Dissertação (Mestrado em Ciências da Religião) - Pontifícia Universidade Católica de São Paulo, São Paulo, 2005.

Mística da água e cidadania, uma análise a partir das águas santas de "São" João Maria, no Contestado. Encontros Teológicos, Florianópolis, ano 19, n. 37, p. 19-35, 2004.

THOMÉ, N. Sangue suor e lágrimas no chão do Contestado. Caçador: UnC, 1992.

São João Maria na história do Contestado: resgate da memória. Caçador: UnC, 1997.

VINHAS DE QUEIROZ, M. Messianismo e conflito social: a guerra sertaneja do Contestado. 2. ed. São Paulo: Ática, 1977.

Recebido: 06/05/2008

Received: 05/06/2008

Aprovado: 23/06/2008

Approved: 06/23/2008 